\title{
Cognitive and value parameters of students' perceptions of the effects of psychoactive substances
}

\author{
Aleksander I. Dontsov ${ }^{\mathrm{a}}$, Elena B. Perelygina ${ }^{\mathrm{b}^{*}}$ \\ a Faculty of Psychology, Lomonosov Moscow State University, Moscow, Russia \\ b Social Psychology Chair, Liberal Arts University - University for the Humanities, Ekaterinburg, \\ Russia
}

*Corresponding author. E-mail: selena8561@yandex.ru

This article sets forth the main results of a study analyzing attitudes toward psychoactivesubstance (PAS) effects. These findings demonstrate the conditionality of social, historic, and cultural views of PAS effects. Despite the threat posed by increasing high school and university students' drug involvement, exploration of this phenomenon in the format of scientific discourse has been limited so far.

In 2014-2015, in Yekaterinburg, Moscow, and Krasnoyarsk a survey to evaluate perceptions of high school and university students about PAS effects was conducted (289respondents, aged 16-22).The methods used included the semantic differential (Peabody Picture Vocabulary Test modified by A.G. Shmelyov), a modified version of the Rokeach Value Survey, word associations, and content analysis.

The use of psychoactive substances is a specific social practice emerging in a certain social context that includes both drug-addicted and PAS-free young people. Examination of the factors affecting the formation of views about PAS effects and the dynamics of youth values is possible by using a bio-psycho-socio paradigm for performing a complex analysis of cognitive, behavioral, and value parameters.

As documented in the respondents' perceptions, distinctive features that are characteristic of drug addicts and that are seen in their behavior area loss of control over behavior, emotions, and volition; changes in value systems; and a tendency to develop a manipulative communication style.

Within the system of their social perceptions the respondents endowed drug-addicted persons with pronounced negative characteristics ("aggressiveness," "addiction," "stupidity" "light-mindedness"). Still, they stated that drug abusers are capable of being active, decisive, cheerful, generous, and flexible. The value analysis demonstrated that terminal values appreciated by the school and university students included health, true friends, love, happy family life, active life, and self-development. Receiving pleasure through methamphetamine intake and a burst of energy through PAS intake were considered worthless even though the survey demonstrated the respondents' use of psychoactive substances.

Keywords: perceptions, value preferences, PAS effects, factor analysis, semantic space 


\section{Introduction}

According to experts of the US National Intelligence Council who analyzed the prospective dynamics of global trends, indicators associated with a widespread "insecurity feeling" rank high. A picture of the world's future with regard to Russian tendencies underlined the finding that Russia faces a "potentially explosive situation due to the spread of AIDS" (Shubin, 2005, p. 13).Such a situation reveals the PAS impact on personality, signifies the close relationships between drug use and HIV/AIDS, and determines the identification of the cognitive and value perceptions of youth about PAS effects.

Before the early 1990s the theme of PAS effects did not exist in academic discourse because information about the drug problem was available only to an inner circle of medical and legal people (Grigirets, 2012, p. 50). At the beginning of the 1990s socioeconomic complexities at the individual and social levels provoked the intense growth of narcomania; yet, there was a possibility for carrying out open sociological research in this field. Despite this possibility, the sociopsychological aspects of PAS use have not yet become a focus of psychological analysis. Perceptions about PAS effects on personality present an aspect of reality in which individual consciousness is objectified. "Technological progress in all spheres of human activity provokes modifications of co-operation, transforms communications and social networks" (Zotova \& Zinchenko, 2014, p. 61).

Perceptions embody social dispositions and cognitive determinants of young people's social behavior and their interpretation of the nature of PAS effects. "The essence of the modern paradigm shift in science is that new objects-complex, selfdeveloping, open systems; their modern status; as well as the main prospects for academic knowledge and technologies-come into researchers' sight" (Zinchenko \& Pervichko, 2012, p. 37).

The examination of PAS effects inherently contains consideration of priorities in the value system of students. The choice between individuals' curiosity satisfaction or craving for new sensations in spite of the declared threats and risks, on the one hand, and their abandonment of these pursuits on the basis of rationalism and morality, on the other, depends primarily on their value system. Yet, Maio and Olson (1998) showed that respondents quite often make their choices impulsively, intuitively, or traditionally. In this respect, it seems sensible to use supplementary methods for analyzing values, and such an effort was made in this research.

Measures against drug use among Russian youth require reinforcement of sustainably negative attitudes toward narcotics and the formation of a confident belief in their harmful impact on human personality. In order to realize this task it is necessary to identify young people's views of PAS effects. A theory that might be productive in answering vital questions related to individuals' attitudes toward narcomania as a social practice and its personality-destructive consequences is socialperceptions theory.

In their research on social perceptions Dontsov and Yemeliyanova demonstrated that one of the functions of such perceptions is "to act as a mechanism regulating the behavior of individual and group subjects" (1984, p.150).For any group of 
young people a perception about the nature of different PAS effects can be a bearer of value, an incentive, or a negative factor in shaping a certain system of attitudes toward risk or PAS use. Youth social perceptions form content-associated elements of group identity and a shared world outlook and its assessment-in particular, mutual understanding of the acceptability or unacceptability of drugs and their positive or negative connotations; "individual self-expression, subjective partiality, the buildup of oneself, the creation of human life cannot be separated from a way of describing the world" (Zinchenko \& Zotova, 2014, p. 53).

Here are the data of a pilot survey conducted by Grebennikova (2010) in Moscow (Moscow State Pedagogical University). In this survey a social-perceptions questionnaire was used to find out the specific views of 100 young people aged 15 to 19 . Half the respondents found it difficult to make a choice in a challenging situation and to assume responsibility for their decision. Nevertheless, $90 \%$ of the young people pointed out the importance of social environment in shaping personality. Thus, the survey highlighted the significance of group behavior and value bearers (peers, classmates, neighbors, relatives) in shaping views of PAS determinants and effects. It is not surprising that such views of the role of the social environment determined a certain group value in the course of communication interaction and in the world outlook of the respondents. It should be taken into account that "values during communication are implied and transmitted together with other things, but they do not become the subject of communication. They are activated only as premise not as a statement" (Luhmann, 2006, p. 229).

\section{Method}

In 2014-2015, in Yekaterinburg, Moscow, and Krasnoyarsk a survey to evaluate the perceptions of high school and university students about PAS effects was conducted (289 respondents, aged 16-22). The testees were asked to evaluate their own subjective reality in the context of sociopsychological security based on the similarity-contrast principle: psychological security, stability, confidence the subject feels/does not feel. Thirty-two 7-point bipolar scales were used. The adjectives were interrelated in four groups within a 4-polar personality-trait model. According to Shmelyov (2002), the use of this 4-polar model makes it possible to "clear" subjective-judgment results not only of social-desirability artifacts but also, in particular, of descriptive factors (characterological perception in this case) in measuring the emotive, value/attitude component of social settings. The results were interpreted with the help of the Big Five scale of personality traits: Friendliness, Intellect, Activeness, Self-control, and Emotional stability. Interpretative names of the factors correlate with the results of the Russian taxonomic study of personality traits.

The survey was aimed at analyzing perceptions of healthy young people without PAS addiction (that is, those not registered by the Drug Prevention Service). The survey was administered to respondents who had never taken psychoactive substances or had used them just once or twice. When the sample was divided into two subgroups, the Mann-Whitney $U$-test did not reveal any significant differences; we could thus examine all the results holistically. 


\section{Results}

The results processed in line with the semantic-differential method (Peabody Picture Vocabulary Test modified by A.G. Shmelyov) showed that the respondents' self-image basically consisted of positive features (90.6\% of the descriptions).A dominating scale in self-description was Self-control, which was used to evaluate a person's level of motivation, organization, and persistence in goal-oriented behavior. From the point of view of the leading qualities providing behavior activation and orientation, the respondents' assessments of themselves emphasized selectivity, practicality, and carefulness. Hence, they were aware of the fact that behavior regulation is enabled by reliability and exactingness, ambitions and persistencecharacteristics that are due largely to a respondent's age.

Taking into account the fact that people can evaluate and perceive a drug addict differently, the respondents were asked to describe the following images: selfimage and image of a drug user. The results were processed via Spearman's rankcorrelation coefficient and factor and principal-component analyses, which made it possible to solve the given tasks using SPSS11.0.

The respondents marked the following traits of their self-image: Critical (1.23), Cheerful (1.46), Tactful (1.36), Sincere (1.61), Flexible (1.16), Active (1.45), Generous (1.36), Practical (1.34), Selective (1.41), Cooperative (1.79), Uninhibited (1.18), Intelligent (1.29), Pleasant (1.71). The dominant features of a drug taker singled out by the respondents were: Light-minded $(-2.19)$, Untactful $(-1.93)$, Agitated (-2.29), Impulsive (-2.07), Unpleasant (-2.07), Aggressive (-1.59), Erratic(-1.61), Indiscriminate $(-1.75)$, Addicted $(-1.81)$, Lazy $(-1.69)$, Stupid $(-1.88)$, Cheerful (1.44), Overconfident (-1.44), Slow (-1.44), Brave (1.08). Thus, the respondents' overall image of a drug addict was negative. They saw such a person as being unreliable, inconstant, unprincipled, overly self-confident, aggressively inclined and as having a low intellect and slow reactions. However, they also saw such an individual as brave and joyful. The results obtained allow us to draw the conclusion that self-image is characterized by adequacy, sociability, activeness, and cheerfulness, while a drug taker receives a low estimate on these characteristics.

A dominant negative scale in the image of a drug taker was Emotional instability (-2.29); this scale assessed self-confidence. The scale Intellect $(-1.88)$ also had a negative value, a rating that testified to the young people's low estimate of the intellectual abilities of a person affected by psychoactive substances. The scale Selfcontrol (-1.37) indicated that the respondents considered a drug addict to be a person incapable of balancing emotions and behavior. A similarly negative scale was Friendliness, which indicated that a drug taker was seen to be aggressively inclined and that it was difficult to constantly maintain fellowship with such a person.

The analysis of self-image and the image of a drug taker based on mean point values was further extended by factor analysis. The reason was that the objective was to define not only dominant, hierarchical relations between the characteristics presented and their corresponding allocation according to their significance (vertical slice) but also semantic, content-based links that united them in separate blocks and factors.

The results of factor-analytical processing gave us the opportunity to identify six significant factors describing PAS addicts. 
The first factor (12.09\% of total variance) involved the following traits:

$\begin{array}{ll}\text { flexible } & .741 \\ \text { combative } & .731 \\ \text { soft } & .700 \\ \text { active } & .630 \\ \text { generous } & .526\end{array}$

The content of the first factor makes it possible to interpret it as Flexibility, which is associated with adaptability, easy disposition, and dissipation. It implies that a PAS taker has to be socially flexible because deviant behavior is socially unacceptable.

The second factor, with $10.84 \%$ of the total variance, consisted of such qualities as:

$\begin{array}{ll}\text { selective } & .715 \\ \text { critical } & .703 \\ \text { careful } & .692 \\ \text { well-organized } & .571 \\ \text { pleasant } & .542\end{array}$

The opposite pole was represented by the following scale:

untrustworthy $\quad-.713$

The content of this factor enables us to treat it as Carefulness, which speaks about suspiciousness, caution, ability to make choices.

The third factor $(9.46 \%$ of the total variance) was made up of these scales:

$\begin{array}{ll}\text { brave } & .667 \\ \text { confident } & .623\end{array}$

The opposite pole embraced the following traits:

overconfident $\quad-.632$

pretentious $\quad-.546$

The content of this factor makes it possible to interpret it as Confidence. This factor characterizes the high ambitions of a drug taker. ties:

The fourth factor, with $8.59 \%$ of the total variance, included the following quali-

persistent $\quad .779$

independent $\quad .764$

The content of the fourth factor allows one to treat it as Independence.

The fifth factor $(7.71 \%$ of the total variance) had these characteristics:

$\begin{array}{ll}\text { practical } & .665 \\ \text { intelligent } & .642 \\ \text { hardworking } & .622\end{array}$

The content of this factor makes it possible to interpret it as Purposefulness. This factor speaks about readiness to act, ability to make decisions, and orientation to goals including deviant ones. 
The sixth factor, accounting for $7.49 \%$ of the total variance, involved the following qualities:

$\begin{array}{ll}\text { peaceful } & .748 \\ \text { cooperative } & .670 \\ \text { tactful } & .523\end{array}$

The content of this factor enables us to treat it as Tactfulness. This factor can imply correctness of conduct and an aspiration to not cause negative public reactions.

The respondents' semantic field built up by the two leading factors, Flexibility and Carefulness, set the respondents' perceptions about a drug user (see Figure 1). The positive semantic space includes the characteristics combative-passive, flexible-rigid, active-inert, soft-rough, sincere-hypocritical, confident-unconfident, principled-adaptive, joyful-sullen, as well as mean-generous, slow-uninhibited. These traits in combination give us the image of a person capable of adapting to the environment and acting decisively and energetically in different situations. Such a person is generous and has easy manners. The opposite part of the semantic field includes the features mild-firm, modest-pretentious, dependent-independent, tactless-tactful, stupid-intelligent, lazy-hardworking, agitated-calm, light-mindedserious. On the basis of these pronounced characteristics the image of a drug taker is of someone who is weak, not clever, and without initiative, with light-mindedness completing the picture.

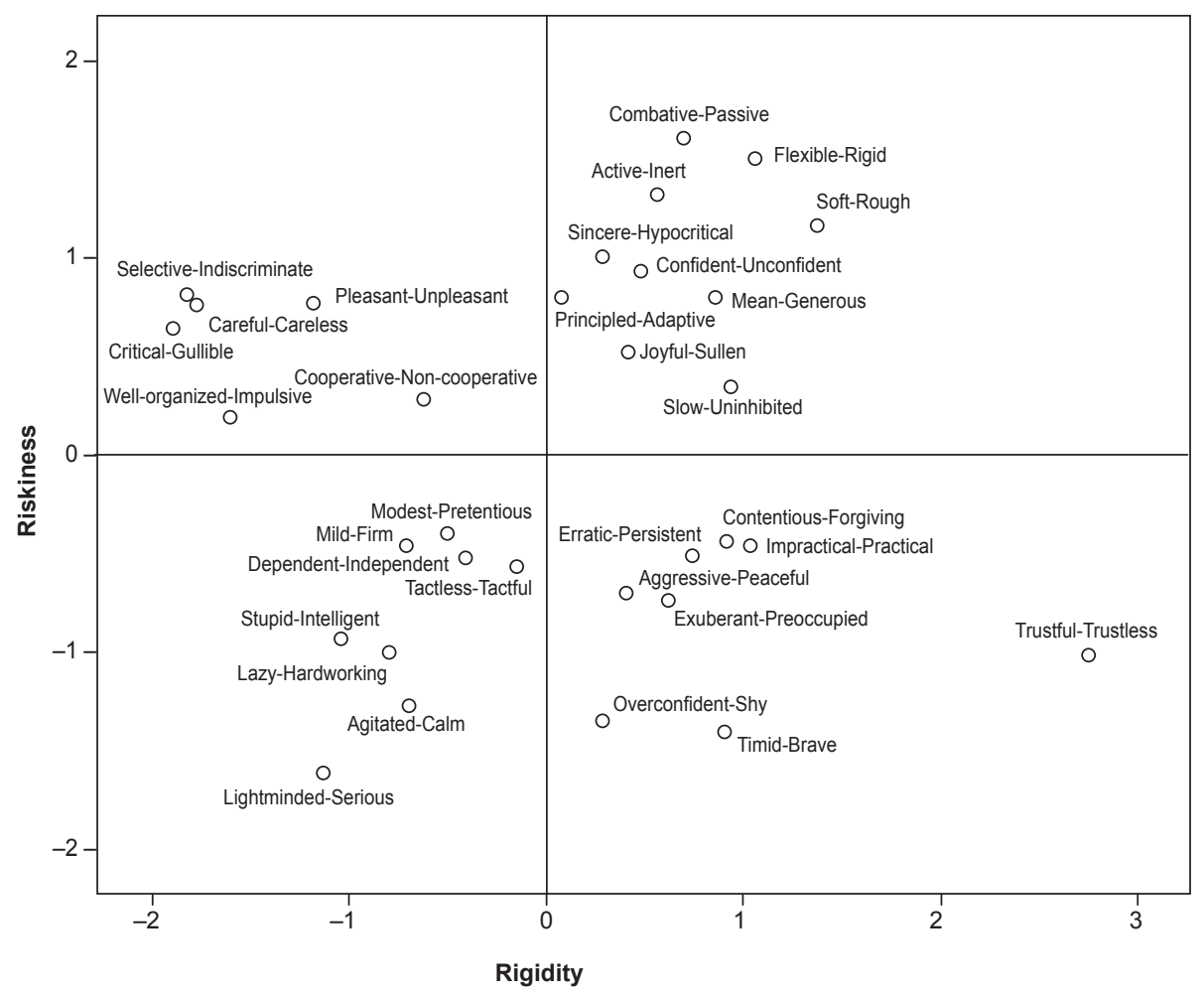

Figure 1. Semantic field of "an image of a drug taker" 
Study of the processes involved in the formation of social perceptions about drug effects can become an important instrument for overcoming the destructive influence of the "narco"-culture mythology that exists among teenagers and for developing critical attitudes toward drugs and an objective assessment of PAS effects.

In its anti-narcotics manual the American Drug Policy Alliance considers early intervention as one of its strategic areas when clinically significant levels of drug abuse or addiction are registered. In order to achieve this intervention, it is necessary to define this level for every teenager from 12 to 17.

Recent prevalence estimates indicate that each year more than 1.7 million youths aged 12 to17 exhibit levels of substance use consistent with the DSM-IV diagnostic criteria for either abuse or dependence. Once adolescent substance use rises to clinically significant levels, such use is unlikely to naturally subside over time and will typically carry over into adulthood. Therefore, early intervention is critical to prevent or minimize the host of social and personal harms that stem from advanced levels of dependence ( $A n$ Exit Strategy. . , 2013, p. 41).

Nowadays new psychoactive substances constantly appear and become consumer goods for young people. In this situation the importance of perception research involving both drug users and drug-free students becomes all the greater.

The student milieu shapes a nuanced communication system and the discourse of particular young people with regard to the PAS impact on personality. The subjects of this communicative practice, which influences social behavior, are not only drug takers but also young people who possess only theoretical knowledge about PAS nature and effects. The study of youth values, beliefs, choices, and attitudes can contribute to formulation of measures that will prevent young people from being involved with drug-addict groups and that will create the basis for antidrug transformations of social behavior. Youth social perceptions about PAS effects revealed in the course of surveys and empirical research are determined largely by norm-value factors intrinsic to social groups and systems. In his works Doise (1994) showed that initial anchoring is connected with the semantic orientation of the PAS problem and its correlation with social behavior patterns existing in the youth environment.

One of the reasons [for drug addiction] is the aspirations of community members for keeping up [a] reputation within "their" circle, i.e., a desire to suit a certain normative model and perpetual efforts to ensure this suitability. By keeping up reputation an individual keeps up and translates a cultural model (Zinchenko \& Perelygina, 2013, p. 109).

In order to specify the results a modified Rokeach Value Survey was applied (Table 1).Terminal values preferred by the respondents included health (physical and mental); true friends; love (affinity and intimacy); happy family life. The least important values were a burst of energy and confidence through PAS intake, pleasure through methamphetamine intake, and the happiness of others (well-being, development and advancement of other people, the nation, and humankind as a 
whole). Thus the respondents appreciated close interpersonal relations, which added to their emotional well-being. Positive consequences resulting from drug intake and other people's successes were insignificant.

Table 1.The respondents' values

\begin{tabular}{|c|c|c|c|}
\hline Terminal values & Rank & Instrumental values & Rank \\
\hline Health (physical and mental) & 1 & Politeness (good manners) & 1 \\
\hline True and close friends & 2.5 & Cheerfulness (sense of humor) & 2 \\
\hline $\begin{array}{l}\text { Love (affinity and intimacy with a } \\
\text { beloved) }\end{array}$ & 2.5 & $\begin{array}{l}\text { Orderliness (neatness), ability to keep } \\
\text { things and business affairs in order }\end{array}$ & 4 \\
\hline Happy family life & 4 & $\begin{array}{l}\text { Good education (breadth of know- } \\
\text { ledge, high culture) }\end{array}$ & 4 \\
\hline $\begin{array}{l}\text { Active life (abundant life full of emo- } \\
\text { tions) }\end{array}$ & 5.5 & $\begin{array}{l}\text { Responsibility (sense of duty, ability } \\
\text { to keep promises) }\end{array}$ & 4 \\
\hline $\begin{array}{l}\text { Growth (self-development, constant } \\
\text { physical and mental perfection) }\end{array}$ & 5.5 & $\begin{array}{l}\text { Independence (ability to act deci- } \\
\text { sively and independently) }\end{array}$ & 7 \\
\hline $\begin{array}{l}\text { Wisdom (mature judgments and com- } \\
\text { mon sense learned from life experi- } \\
\text { ence) }\end{array}$ & 8.5 & $\begin{array}{l}\text { Self-control (self-discipline, re- } \\
\text { straint) }\end{array}$ & 7 \\
\hline Good job & 8.5 & Honesty (truthfulness, sincerity) & 7 \\
\hline $\begin{array}{l}\text { Prosperous life (absence of financial } \\
\text { problems) }\end{array}$ & 8.5 & Can-do attitude (discipline) & 10.5 \\
\hline $\begin{array}{l}\text { Cognition (opportunity to broaden } \\
\text { world outlook, get extra education, take } \\
\text { culture and intellect to a new level) }\end{array}$ & 8.5 & $\begin{array}{l}\text { Rationalism (ability to think straight } \\
\text { and logically, take well-conceived, } \\
\text { rational decisions) }\end{array}$ & 10.5 \\
\hline $\begin{array}{l}\text { Freedom (self-sufficiency, independent } \\
\text { judgments and actions) }\end{array}$ & 11.5 & $\begin{array}{l}\text { Strong will (ability to get one's own } \\
\text { way, do not give up) }\end{array}$ & 10.5 \\
\hline $\begin{array}{l}\text { Confidence (inner harmony, freedom } \\
\text { from inner conflicts and doubts) }\end{array}$ & 11.5 & $\begin{array}{l}\text { Tolerance (to other people views and } \\
\text { opinions, ability to forgive others' } \\
\text { fault and delusion) }\end{array}$ & 10.5 \\
\hline $\begin{array}{l}\text { Public recognition (respected by the } \\
\text { people around, team, associates) }\end{array}$ & 14 & $\begin{array}{l}\text { Courage to stand up for one's opini- } \\
\text { on, point of view }\end{array}$ & 14 \\
\hline $\begin{array}{l}\text { Productive life (maximum realization } \\
\text { of one's potential, strengths, and abili- } \\
\text { ties) }\end{array}$ & 14 & $\begin{array}{l}\text { Open-mindedness (ability to under- } \\
\text { stand others' stand, respect for } \\
\text { others' tastes, customs, habits) }\end{array}$ & 14 \\
\hline $\begin{array}{l}\text { Entertainments (pleasant, care-free } \\
\text { pastimes; lack of responsibility) }\end{array}$ & 14 & Sensitivity (attention to people) & 14 \\
\hline Creativity (ability to create) & 16 & High aspirations (high life claims) & 16 \\
\hline $\begin{array}{l}\text { Beauty of nature and art (ability to } \\
\text { experience beauty in nature and in art) }\end{array}$ & 17,5 & Efficiency (diligence, productivity) & 17 \\
\hline $\begin{array}{l}\text { Happiness of others (well-being, } \\
\text { growth, and success of other people, } \\
\text { the nation, humankind on the whole) }\end{array}$ & 17.5 & $\begin{array}{l}\text { Uncompromising attitude to one's } \\
\text { own and others' faults }\end{array}$ & 18 \\
\hline $\begin{array}{l}\text { Pleasure through methamphetamine } \\
\text { intake }\end{array}$ & 19 & $\begin{array}{l}\text { Strong emotions (even with the help } \\
\text { of PAS) }\end{array}$ & 19 \\
\hline $\begin{array}{l}\text { Burst of energy and confidence } \\
\text { through PAS intake }\end{array}$ & 20 & $\begin{array}{l}\text { Gain of satisfaction and confidence } \\
\text { (with dopamine stimulation if } \\
\text { needed) }\end{array}$ & 20 \\
\hline
\end{tabular}


Among instrumental values our respondents chose, for example, politeness, cheerfulness, orderliness in life and business affairs, good education, and responsibility. Insignificant values included gaining satisfaction and confidence (with dopamine stimulation if needed); strong emotions (even with the help of PAS); uncompromising attitude to one's own and others' faults. Thus, one can assume that when achieving their goals the respondents were guided by their personal discipline and positive thinking. They did not need strong emotions stimulated by PAS intake and struggling against other people's faults.

A survey based on social-perception theory showed how drug use transforms social perceptions about narcotics themselves (Bovina, Dvoryanchikov, Konoplyova, Kobalyov, \&Konkin, 2012).In particular, such experience had a dual effect on drug social perceptions: on the one hand, the respondents who used drugs evaluated them in a more positive manner than those who had not used them; on the other, they widened the notion of narcotic, adding strong alcoholic drinks to it. Therefore, one can speak of social-perception differentiation intrinsic to drug users and drug-free people.

Let us turn our attention to how important the formation of PAS-effect perceptions is. The parameters of cognitive and value perceptions reveal their significance theoretically as well as practically. Here we can speak about the deficit of teenagers' knowledge about essential PAS characteristics, the after-effects of their use, the biochemical process in the body upon PAS intake, and the prospects of a personality metamorphosis of drug takers. Peirce (2000) gave a detailed explanation of the multilevel nature of cognition processes:

Understanding of a word or a formula can be achieved either through, in the first place, such an awareness of it that might allow one to use it correctly; or, second, through abstract analysis of the notion or understanding of how it intellectually relates to other notions; or, third, through knowledge of phenomenal or practical results of this notion affirmation (Pierce, 2000, p. 225).

The survey context draws attention to the fact that social perceptions perform comprehensive functions: defensive, communicative, affecting an individual's behavior orientation, legitimizing corresponding social relations, and constructivedirected to the formation of the social identity of the communication-interaction subject. Also, depending on the sociocultural context a leading role is fulfilled by these functions, and "social perceptions elaborated by a social group and clothed in specific words and terms are embedded and circulating in society's 'identification matrix,' i.e., in a certain system of meanings set by the culture" (Zotova \& Solodukhina, 2013, pp. 80-81).

Contemporary research has a tendency toward comprehensive analysis when examining the problem of PAS effects on personality in terms of a bio-psycho-socio paradigm. Considering PAS effects through a set of behavioral, cognitive, value, emotional, and physiological parameters provides the opportunity to observe the distortion of cognitive ability and volition and the alteration of sociocultural orientations, consciousness, and self-awareness (N.F.Fleming, S.V.Dvoruak, T.A.Donskikh, N.V.Dmitrieva, I.B.Bovina, I.B.Yurevich, L.G.Leonova, L.A.Tsvetkova, N.V. Dvoryanchikov, and others). 
Among reasons for the great vulnerability of youth is self-concept instability. Thus, some of its specific features can act as a drug-addiction factor. It is common knowledge that self-concept is shaped under the influence of the social environment and that it predetermines a young person's interaction with it. Consequently, the more unstable social factors are, the less stable self-concept appears to be. Another important aspect of the self-concept of youth is body image. Change and development of their bodies never stops, and the same happens to their self-concept, together with ways of interacting with the environment. Proneness to crises and conflicts is also explained by the fact that young people experience not only the need to join certain social groups but also, at the same, the need to separate themselves from their habitual environment and even to confront it in order to attain and to unleash the individual self. It is obvious that self-perception is a powerful phenomenon; it requires continual self-expression and discharge, but, simultaneously, it is indefinite, filled with the experiences of other people: parents, older friends, and other reputable people. This contradiction between potential ability and the real substance of activity generates inner tension, whose release becomes urgent and vital. In young people's opinion the most effective way to defuse tension is often through some form of deviant behavior, including drug-taking (Raigorodsky, 1996).

The study of social perceptions can be useful for understanding the dynamics of human/world relationships, especially with regard to health (Foster, 2003; Howarth, Foster, \& Dorrer, 2004). Although it seems natural to examine constructs that respondents use to describe drug use, only a small number of research papers in this area can be found: tobacco-use perceptions (Echabe, Guede, \& Castro, 1994; Stjerna, Lauritzen, \&Tillgren, 2004), perceptions about drug or alcohol abuse among particular groups of the population (DaSilva \& Padilha, 2011), parents whose children are drug takers (Nuño-Gutiérrez, Álvarez-Nemegyei, \& Rodriguez-Cerda, 2008), students (Cabral, Da Cruz Farate, \& Duarte, 2007), teachers (Martini \& Furegato, 2008), heavy drinkers (Alvarez, 2004; daSilva \& deSouza, 2005). A paper by Demers, Kishchuk, Bourgault, \& Bisson (1996) is of special interest. They considered relationships between strong alcohol use and eight social perceptions. They argue that perceptions should be examined independently of social context and the respondents' life experience. The significance of the phenomenal characteristics of notions in their functioning and interaction is emphasized in the framework of discursive psychology. For students' perceptions, individual mental operations aimed at gaining and processing information about PAS effects on personality equal in importance the social construction of their actions, attitudes, interactions, and identity(Potter, 1996; Wetherell,1996).

With the aim of deepening our study, we used the free-association method. It resulted in 1,282 associations to the notion psychoactive substances; these average, 4.4 associations per testee. Content analysis of the associations included in the core and periphery of PAS perceptions was conducted. The data obtained are as follows: substances (pep pills, narcotics, alcohol) $-37.01 \%$, situation of substance intake (music, club) $-17.41 \%$, effects upon intake (energy, efficiency) $-22.4 \%$. Therefore, in a restructured variant all the categories made up $76.82 \%$.

In the course of the empirical study 1,096 associations were stated in response to the word narcotics, which on average is 3.8 elements per subject. A conceptual dictionary contains 189 different words and word combinations for narcotics. In 
the study, 642 associations entered the core and periphery zones of perceptions about drugs (58.58\% of the total associations produced by the respondents).

Table 2. The structure of drug perceptions

\begin{tabular}{ll}
\hline Structural elements & Notions/associations (frequency; average rank) \\
\hline Core zone of social perception & Addiction $(158 ; 2.17)$ \\
& Disease $(139 ; 2.16)$ \\
& Harm $(127 ; 2.29)$ \\
Zone of potential perception alteration & Syringe $(44 ; 2.69)$ \\
& Destruction $(41 ; 2.78)$ \\
& Death $(26 ; 2.89)$ \\
& Problems $(20 ; 2.99)$ \\
Periphery perception system itself & Money $(19 ; 3.01)$ \\
& Loneliness $(25 ; 3.16)$ \\
& Crime $(23 ; 3.34)$ \\
& Heroin $(20 ; 3.69)$ \\
\hline
\end{tabular}

As can be seen in Table 2 the core-zone elements are specified by the periphery elements: on the one hand, the core-zone elements indicate the physical consequences of drug intake: "addiction," "disease" (the core zone), "destruction," "death" (the periphery system); on the other, they point out the social effects of drug intake: "problems," "loneliness," "crime" (the periphery system). Thus, differences existed in PAS and drug perceptions: PAS effects do not convey a pronounced negative evaluation. In addition, the content of the perceptions included means of drug use: "syringe," "money," "heroin." Here we also observe an essential difference in the PAS and drug perceptions: whereas psychoactive substances were associated with smoking and ingesting pep pills, narcotics were associated with intravenous injections ("syringe," "heroin"). The notions in the core bear strictly negative emotional coloring ("addiction," "disease," "harm"). In addition, narcotics perceptions lack categories describing situations of their intake, while PAS perceptions give a clear picture of this aspect. We can thus conclude that psychoactive substances and their intake were more pronounced in the youths' practical experience in comparison with narcotics.

In addition, the elements in the drug-perception core zone coincide with narcomania perception elements indicated in Beresina's survey (2011) as well as in the survey by Bovina and her colleagues data (2012). We can conclude that there is evidence of object-perception equality, and, hence, stability, sustainability, and a high degree of consistency in youths' perceptions of narcotics.

Comparison of the content and structure of the perceptions show that the youths' perceptions of psychoactive substances were less consistent and homogeneous than their drug perceptions. Such data as the numerical dominance of notions expressed in response to the stated word combination psychoactive substances over the number of entries in a conceptual dictionary (290 and 189 correspondingly) confirm this conclusion. Besides, the frequency of associations entering the core of drug perceptions was a lot higher than the frequency of core components in PAS perceptions. Thus, for instance, the notion narcotics (the most numerous in 
the core structure of PAS perceptions) was stated by just $29 \%$ of the respondents, while the notion addiction (the most numerous in the core structure of narcotics perceptions) was given by $59 \%$ of the respondents. Finally, the core of the drug presentations contained $66 \%$ of the total associations entering its structure. In the case of PAS perceptions this indicator accounted for just $41 \%$.

To make our prototypical analysis more precise, content analysis was carried out including all the answers of the respondents. As a result of restructuring materials the following data were obtained: means ("syringe," "heroin") $-11.9 \%$, physical effects ("death,"“disease") - 28.25\%, social consequences ("loneliness," "problems") $22.31 \%$. In a restructured variant all the categories made up $62.46 \%$.

Therefore, drug perceptions in the youths' consciousness were mainly specified by the negative effects of their use, both physical and social (50.56\%). At the same time the negative character of PAS effects was represented in the youths' perceptions to a smaller degree $(22.40 \%)$. This difference can be explained by an intense media campaign aimed at building awareness of negative drug-intake effects, while PAS effects were given considerably less attention. Thus, the young people possessed limited knowledge about the harm caused by psychoactive substances. "The lack of security takes the lead, starts to determine motive rebuilding, rearranging this motivation and specifically transforming other groups of basic needs, psychic characteristics and personal traits" (Dontsov \& Zotova, 2013, p. 81).

However, for the substances themselves (narcotic or psychoactive) a reverse tendency can be observed. Narcotic means were much less well represented in the youths' consciousness than psychoactive substances $(11.9 \%$ and $37.01 \%$, correspondingly). One probable explanation is the greater availability (real or potential) of PAS for young people.

Further analysis involved categorization of psychoactive substances. All associations mentioned were divided into groups of psychoactive substances regarded as legal and illegal under Russian Federation legislation (Figure 2).

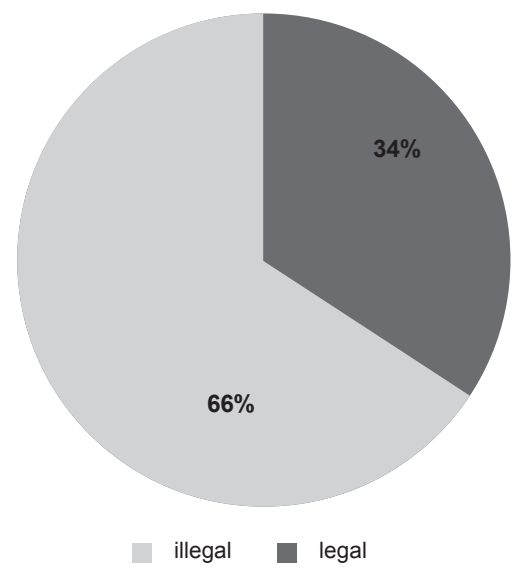

Figure 2.The proportion of legal and illegal substances (under Russian Federationlaw) in the stucture of youths'perceptionsabout PAS 
The group of illegal means contained substances whose free circulation is forbidden and regulated by the state as well as those means distribution of which is restricted and which are subject to state control according to Russian Federation legislation and international agreements.

The subjects did not mention such psychoactive substances as tea and coffee, which are consumed on a regular basis. In the youths' perceptions the most common legal psychoactive substances were cigarettes, alcohol, and energy shots. Still, the share of legal substances was much smaller compared with illegal ones, whereas perceptions about their aftereffects in comparison with the aftereffects of narcotics were insignificant. To put it differently, young people in their consciousness mainly relate narcotics to psychoactive substances, but they remain unaware of the aftereffects of their use when classifying them as psychoactive substances. In other words, the cognitive parameters of high school and university students' perceptions about PAS effects were vague, and the correlation of drug intake and the distortion of personal characteristics was realized and considered to a dramatically limited extent. As has been observed, value parameters "will be partly defined by the situation specifics, by the way the question is asked and by whom it is put; it will depend on how well-shaped an individual's perception of his own value system is" (Podolsky, 2012, p. 363).

\section{Conclusion}

In the context of a bio-psycho-socio paradigm the study demonstrated that insufficiently formed school and university students' perceptions about their own value attitudes and the instability of their self-concept determined their negative perceptions of narcotic effects alongside their tolerant perceptions of PAS effects. In the study the combination of cognitive and value parameters indicated a vector of the change in behavior patterns through considerable representation of psychoactive substances in the practical experience of youth.

\section{Acknowledgements}

The article was supported with a grant from the Russian Science Foundation (project № 16-18-00032).

\section{References}

Alvarez, A. A. (2004). Representacion social delalcoholismo de personas alcohólicas [Social perceptions of alcoholism with alcoholics]. Psicologia em Estudo, 9(2), 151-162. doi: 10.1590/ s1413-73722004000200002

Berezina, E. B. (2011). Soderzhanie i struktura obydennyh predstavlenij o boleznjah v molodezhnoj srede [The structure and content of ordinary youths' perceptions about diseases].(Unpublished doctoral dissertation).Lomonosov Moscow State University: Moscow. Retrieved from http://istina.msu.ru/media/dissertations/dissertation/2fa/ec2/22682361/Berezina_ EB_avtoreferat.pdf

Bovina, I. V., Dvoryanchikov, N. V., Konoplyova, I. N., Kobalyov, M. A., \& Konkin, V. Y. (2012). Narkotiki i narkomany: Osobennosti socialnyh predstavlenij v dvuh gruppah molodezhi 
[Narcotics and drug takers: Specifics of social perceptions in two youth groups]. Psihologicheskaja Nauka i Obrazovanie [Psychological Science and Education], 3. Retrieved from http://psyedu.ru/files/articles/psyedu_ru_2012_3_3026.pdf

Cabral, L. R., Da Cruz Farate, C. M., \& Duarte, J. C. (2007). Da unidade de investiga çãoemciências da saúde [Social representations of alcohol in higher education students]. Domíniode Enfermagem [The Power of Nursing], 4, 69.

da Silva, S.E.D., \& de Souza, M.J. (2005). Alcoólatra, Sim; Bêbado, Não: Representações Sociais de Alcoolistas Abstêmios Sobre o Alcoolismo [Alcoholic, yes; drunk, no: Social representations of abstemious alcoholics on alcoholism]. Escola Anna Nery Revistade Enfermagem [Anna Nery School Journal of Nursing], 9, 293-295.

da Silva, S.E.D., \& Padilha, M.I. (2011). História devida e o alcoolismo: Representa çõessociais de adolescentes [Life history and alcoholism: Social representations of adolescents]. Revista Mineirade Enfermagem [Nursing Journal of Minas Gerais], 15(1), 70.

Demers, A., Kishchuk, N., Bourgault, C., \& Bisson, J. (1996). When anthropology meets epidemiology: Using social representations to predict drinking patterns. Substance Use \& Misuse, 31(7), 847-871.doi: 10.3109/10826089609063960

Doise, W. (1994). Fenomen ankerovki v issledovanijah socialnyh reprezentatsij [The phenomenon of anchoring in studying social representations]. Psihologicheskij Zhurnal [Psychological Journal], 1, 19-26.

Dontsov, A.I., \&Yemeliyanova, T.P. (1984). Konceptsija socialnyh predstavlenij v sovremennoj francuzskoj psihologii [The concept of social perceptions in contemporary French psychology]. VoprosyPsihologii [Issues in Psychology],1, 147-152.

Dontsov, A.I., \& Zotova, O.Y. (2013).Reasons for migration decision making and migrants security notions. Procedia-Social and Behavioral Sciences, 86, 76-81. doi: 10.1016/j. sbspro.2013.08.528

Echabe, A.E., Guede, E.F., \& Castro, J.L.G. (1994). Social representations and intergroup conflicts: Who's smoking here? European Journal of Social Psychology, 24, 339.doi: 10.1002/ ejsp. 2420240304

An Exit Strategy for the Failed War on Drugs. A Federal Legislative Guide. (2013). Retrieved from http://www.drugpolicy.org/sites/default /files/DPA_Exit\%20Strategy_Federal\%20Legislative\%20Guide.pdf

Foster, J.L.H. (2003). Representational projects and interacting forms of knowledge. Journal for the Theory of Social Behavior, 33, 231-244.doi: 10.1111/1468-5914.00216

Grebennikova, O.V. (2010). Osobennosti socialnyh predstavlenij sovremennyh rossijskih podrostkov [Peculiarities of social representations in modern Russian teenagers]. Psihologicheskie Issledovanija [Psychological Research], 2(10). Retrieved from http://psystudy.ru/ index.php/num/2010n2-10/308-grebennikova10.html

Grigirets, S.I. (2012). Narkotizacija molodezhi: Harakteristika, prichiny, profilaktika [Youth narcotization: Characteristics, causes, preventive measures]. Vladivostok, Russia: 48 hours.

Howarth, C., Foster, J.L.H, \& Dorrer, N. (2004). Exploring the potential of the theory of social representations in community-based health research. And vice versa? Journal of Health Psychology, 9, 229-243. doi: 10.1177/1359105304040889

Luhmann, N. (2006). Differentsiatsija [Differentiation]. Moscow: Logos.

Maio, G.R., \& Olson, J.M. (1998). Values as truisms: Evidence and implications. Journal of Personality and Social Psychology, 74, 294-311. doi: 10.1037/0022-3514.74.2.294

Martini, J.G., \& Furegato, A.R.F. (2008).Representacion essocialessegún los profesores al respect del uso de drogas en una escuela de educación básica [Teachers' social representations of drug use in a secondary school]. Revista Latino-Americana de Enfermagem [Latin American Journal of Nursing], 16, 601-606. doi: 10.1590/S0104-11692008000700016 
Nuño-Gutiérrez, B.L., Álvarez-Nemegyei, J., \& Rodriguez-Cerda, O. (2008). Social representations used by the parents of Mexican adolescent drug users under treatment to explain their children's drug use: Gender differences in parental narratives. Adolescence, 43, 351-371.

Pierce, C. S. (2000). Chto takoe znachenie [What is the meaning?]. In Selected Philosophic Works (pp. 171-185). Moscow: Logos.

Podolsky, D.A. (2012). Nravstvennye cennosti podrostkov [Moral values of teenagers]. In A.L. Zhuravlyov\& A.V. Yurevich (Eds.), The morality of contemporary Russian society: Psychological analysis. Moscow: Institute of Psychology RAS.

Potter, J. (1996). Representing reality: Discourse, rhetoric and social construction. London: Sage. doi: $10.4135 / 9781446222119$

Raigorodsky, D.Y. (1996). Teorii lichnosti v zapadnoevropejskoj i amerikanskoj psihologii [Personality theory in Western and American psychology]. Samara, Russia: Bakhrakh.

Shubin, A. (Ed.). (2005). Doklad Nacionalnogo Razvedyvatelnogo Soveta SShA "Kontury mirovogo budushhego" [The USA National Intelligence Council report "Outlines of the world's future"]. In Russia2020: The country's future under global change (pp. 7-9). Moscow: Evropa.

Shmelyov, A.G. (2002). Psikhodiagnostika lichnostnykh chert [Psychodiagnosis of Personality Traits]. St. Petersburg: Rech.

Stjerna, M.-L., Lauritzen, S.O., \& Tillgren, P. (2004). "Social thinking” and cultural images: Teenagers' notions of tobacco use. Social Science \& Medicine, 59, 573-583. doi:10.1016/j. socscimed.2003.11.003

Wetherell, M. (1996).Group conflict and the social psychology of racism. In M. Wetherell (Ed.), Identities, Groups and Social Issues (pp. 17-24). London: Sage.

Zinchenko, Y.P., \& Perelygina, E.B. (2013). A secure city: Social-psychological aspects. Procedia - Social and Behavioral Sciences, 86, pp. 104-109. doi:10.1016/j.sbspro.2013.08.533

Zinchenko, Y.P., \& Pervichko, E.P. (2012). Postneklassicheskaja metodologija v klinicheskoj psihologii: Nauchnaja shkola L.S. Vygotskogo-A.R. Lurija. [Post-non-classic methodology in clinical psychology: L.S. Vygotsky-A.R. Luria scientific school]. Nacionalnyj psihologicheskij zhurnal [National Psychological Journal], 8, 32-45.

Zinchenko, Y.P., \& Zotova, O.Yu. (2014). Security in the worldview of Russians. Psychology in Russia: State of the Art, 7(1), 50-61. doi:10.11621/pir.2014.0106

Zotova, O.Y., \& Solodukhina, O.S. (2013). Predstavlenie o rodine kak socialno-psihologicheskij fenomen bezopasnosti [Motherland notions as a sociopsychological phenomenon of security]. In Multicultural Reality: Stability and Security (pp. 45-49). Yekaterinburg, Russia: University for Humanities.

Zotova, O.Y., \&Zinchenko, Yu.P. (2014). Parents' notions of Internet information aimed at children. Procedia-Social and Behavioral Sciences, 146, 61-67. doi:10.1016/j.sbspro.2014.08.087

Original manuscript received January 18, 2016 Revised manuscript accepted February 22, 2016

First published online September 30, 2016 